Received 17.07.2017

Reviewed $\quad 09.12 .2017$

Accepted 15.12.2017

A - study design

B - data collection

C - statistical analysis

D - data interpretation

E - manuscript preparation

F - literature search

\title{
Diurnal water temperature dynamics in lowland rivers: A case study from Central Poland
}

\author{
Maksym A. LASZEWSKI ${ }^{\mathrm{ABCDEF} \bowtie}$
}

University of Warsaw, Faculty of Geography and Regional Studies, Department of Hydrology, ul. Krakowskie Przedmieście 30, 00-927 Warszawa, Poland; e-mail: m.laszewski@uw.edu.pl

For citation: $\quad$ Laszewski M.A. 2018. Diurnal water temperature dynamics in lowland rivers: A case study from Central Poland. Journal of Water and Land Development. No. 36 p. 89-97. DOI: 10.2478/jwld-2018-0009.

\begin{abstract}
The paper examines spatial and seasonal variations in diurnal water temperature dynamics in lowland rivers. Temperature data was obtained from digital temperature loggers located in nine sites across the Mazovian Lowland during the hydrological year 2016. On the basis of measurement data, mean, maximum, and minimum daily ranges were calculated in the monthly timescale, as well as the timing of extreme temperatures during the day. The results indicate that water temperature dynamics of lowland rivers have a clear seasonal pattern, with the highest variations of temperature in May and June and the lowest in January. Statistically significant differences were found in the daily temperature range between groups of the investigated sites; a higher diurnal temperature range was observed in sites draining a smaller catchment area, while larger rivers were generally more thermally stable in the daily timescale. There was also found an effect of anthropopressure on diurnal temperature dynamics in urbanized catchments, mainly due to impoundments and sewage inflows. Maximum water temperature in the studied sites usually occurred in the morning, from 06:00 to 10:00 CEST, while minimum temperature occurred in the late afternoon, from 14:00 to 18:00 CEST. Spatially, the timing of the maximum and minimum water temperatures during the day was similar in all of the investigated sites, with no statistically significant differences. However, cluster analysis indicated that in the summer half of the year the timing of the extreme temperatures was more varied between investigated sites. The results provide new insight into short-term river thermal behaviour and they are valuable in the context of game fisheries due to the significance of daily temperature variations in fish activity and feeding.
\end{abstract}

Key words: Central Poland, diurnal dynamics, lowland rivers, water temperature

\section{INTRODUCTION}

Stream water temperature is an important and interesting hydrological variable, mainly due to its ecological significance, as well as the possibility of using as an indicator of climate change and anthropopressure [MARSZELEWSKI, PIUS 2015; WEBB et al. 2008]. In stream networks variations of water temperature are observed both spatially and temporally, and this last variability can be analysed further in two timescales - seasonally and daily [MALCOLM et al. 2004]. While seasonal temperature changes are generally associated with climatic variables and hydrogeological properties, such as groundwater inflows [JOHNSON et al. 2014; WEBB, ZHANG 1997], daily temperature dynamics are related to short-term cycles of solar radiation, air temperature, and cloud cover, modified by site-specific properties, such as riparian vegetation shade [EVANS et al. 1998; GARNER et al. 2014]. It must be emphasized that daily temperature signals play a crucial role in the stream environment due to affecting short-term metabolic rates, feeding, and activity of all poikilothermic organisms, such as macroinvertebrates and fish [OLIGNY-HEBERT et al. 
2015]. Furthermore, it was suggested that species diversity is directly correlated with dial temperature pulse - reaches which experience significant daily temperature variations are characterized by higher biotic diversity [VANNOTE et al. 1980].

The diurnal dynamics of water temperature in Poland was investigated in lake ecosystems [SKOWRON, PIASECKI 2016], but in the case of streams and rivers, mainly due to the lack of reliable, high-resolution water temperature data, this subject was discussed occasionally. For example, such studies were carried out by WIEJACZKA [2007], ŁASZEWSKI [2013] and RAJWA-KULIGIEWICZ et al. [2015], but they were based on short-term measurement campaigns and generally referred to single river locations. However, in the case of streams flowing throughout urban and agricultural areas, where many factors may affect the thermal continuum, the diurnal cycle of water temperature can be spatially complex and its evaluation may be useful from the point of view of environmental and fishery managers [MALCOLM et al. 2004]. Thus, this paper examines spatial and seasonal variations of water temperature dynamics in small lowland rivers. In particular, specific objectives were to (1) investigate changes in diurnal water temperature dynamics throughout the year (2); assess the dynamics of water temperature in the context of varied stream and catchment properties; and (3) characterize the timing of the maximum and minimum water temperatures during the day.

\section{MATERIALS AND METHODS}

Water temperature was recorded from the $1^{\text {st }}$ of November 2015 to the $31^{\text {st }}$ of October 2016 in nine lowland catchments located in central Poland in the proximity of Warsaw (Fig. 1). Sites were distributed across the Jeziorka, Rządza, Świder, and Utrata rivers, which belong to the Vistula River catchment, and represent small-sized lowland rivers. The studied rivers flow through glacier depositional plains and their catchments are characterized by an average annual air temperature of approximately $8-9^{\circ} \mathrm{C}$ and long-term annual precipitation in the sum of $550 \mathrm{~mm}$. The streambed of the rivers consists mainly of medium and coarse sand, with gravel and boulders occurring locally. The measurement sites are varied in terms of the drained catchment area, their land use, and riparian shade; some of them are additionally subjected to human impacts (Tab. 1). The sites were a part of the water temperature monitoring network of the Mazovian lowland rivers, described in more detail in previous studies [ŁASZEWSKI 2016].

Temperature was measured automatically with the use of digital data loggers installed temporally in the river channels. HOBO U22-001 recorders (Onset Computer Corporation, USA) were used for the study, with an accuracy of $0.2^{\circ} \mathrm{C}$ and a resolution of $0.01^{\circ} \mathrm{C}$. In all cases temperature recorders were installed in perforated PVC pipes attached to blocks of concrete and hidden on the streambed. Devices were located in shallow riffles at a depth up to $60 \mathrm{~cm}$, where a crosssectional water temperature gradient was not observed due to turbulent flow and mixing. To ensure the capture of daily temperature extremes, a temporal resolu-

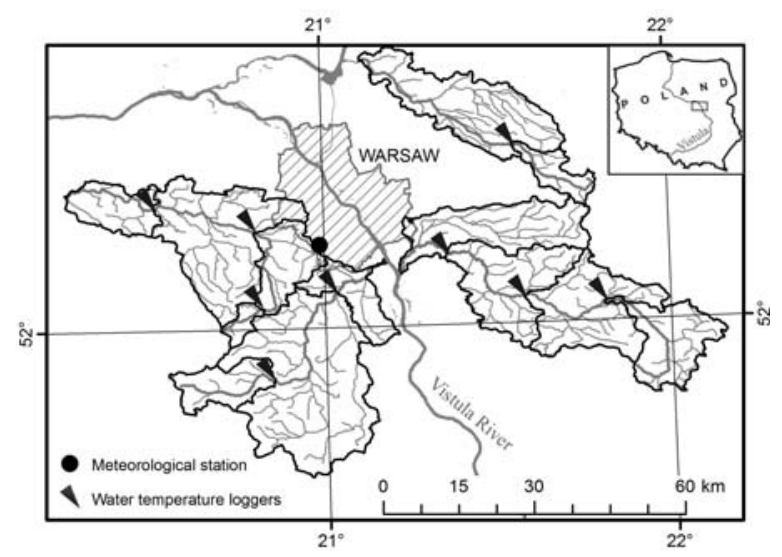

Fig. 1. Study area with the locations of water temperature loggers; source: ŁASZEWSKI [2016], modified

Table 1. Characteristics of measurements profiles

\begin{tabular}{|c|c|c|c|c|c|c|c|c|c|}
\hline River & Profile & $\begin{array}{c}\text { Distance } \\
\text { from source } \\
\mathrm{km}\end{array}$ & $\begin{array}{l}\text { Catchment } \\
\text { area } \\
\mathrm{km}^{2}\end{array}$ & $\begin{array}{l}\text { Mean } \\
\text { catchment } \\
\text { elevation } \\
\text { m a.s.l. }\end{array}$ & $\begin{array}{c}\text { Riparian } \\
\text { shade } 5 \mathrm{~km} \\
\text { upstream } \\
\%\end{array}$ & $\begin{array}{l}\text { Urban } \\
\text { area } \\
\%\end{array}$ & $\begin{array}{l}\text { Agricultural } \\
\text { area } \\
\%\end{array}$ & $\begin{array}{l}\text { Forested } \\
\text { area } \\
\%\end{array}$ & Description \\
\hline Jeziorka & $\mathrm{J} 1$ & 23.5 & 137.8 & 178 & 77.0 & 1.2 & 75.9 & 22.4 & quasi-natural reach \\
\hline Jeziorka & $\mathrm{J} 2$ & 57.0 & 854.0 & 142 & 72.0 & 7.3 & 73.8 & 18.4 & quasi-natural reach \\
\hline Rządza & R1 & 24.0 & 83.1 & 170 & 88.0 & 5.5 & 59.8 & 34.4 & reach downstream from pond \\
\hline Świder & $\mathrm{S} 1$ & 32.5 & 219.5 & 175 & 5.0 & 4.6 & 66.1 & 29.1 & $\begin{array}{l}\text { quasi-natural reach without } \\
\text { riparian shade }\end{array}$ \\
\hline Świder & $\mathrm{S} 2$ & 51.6 & 550.7 & 161 & 8.0 & 4.3 & 70.5 & 25.1 & quasi-natural reach \\
\hline Świder & S3 & 79.3 & 853.3 & 154 & 73.0 & 5.0 & 67.4 & 27.4 & quasi-natural reach \\
\hline Utrata & U1 & 10.3 & 35.6 & 155 & 74.0 & 3.7 & 60.6 & 35.7 & quasi-natural reach \\
\hline Utrata & $\mathrm{U} 2$ & 32.3 & 198.4 & 118 & 56.0 & 27.1 & 56.2 & 15.3 & $\begin{array}{l}\text { regulated reach, downstream } \\
\text { from sewage inflows and } \\
\text { reservoir releases }\end{array}$ \\
\hline Utrata & U3 & 55.0 & 661.0 & 106 & 0.0 & 25.5 & 64.1 & 9.8 & $\begin{array}{l}\text { regulated reach, downstream } \\
\text { from sewage inflows }\end{array}$ \\
\hline
\end{tabular}

Source: ŁASZEWSKI [2016], modified. 
tion of 30 minutes between measurements was established. Data on the mean monthly air temperature was obtained from the meteorological station in Warsaw Okęcie, operated by the Institute of Meteorology and Water Management - National Research Institute (Pol. Instytut Meteorologii i Gospodarki Wodnej Państwowy Instytut Badawczy - IMGW-PIB).

On the basis of the raw measurement data, daily mean and daily range of water temperature was calculated. This was a base for estimation of monthly mean, maximum, and minimum water temperature ranges, as well as mean monthly water temperatures. To provide information about the timing of the extreme water temperatures during the day, relative frequency of the daily extremes timing was calculated as a frequency of the different hours to reach daily minimum and maximum water temperatures referred to all days during the winter (XI-IV) and summer (V-X) halves of the year. Heat maps, which are commonly used for presentation of hydrogeochemical data, such as ion concentrations [ŻELAZNY 2012], were applied for relative frequency visualisation. The course of the water temperature on the specific days of the year equinoxes and solistices - were presented on the graphs. A Kruskal-Wallis non-parametric test, selected due to working with a non-normally distributed data, was run for check if there are statistically significant differences $(p<0.01)$ between daily water temperature ranges in all analysed sites, as well as for post-hoc multiple comparisons of groups similar in terms of daily water temperature range. Moreover, hierarchical cluster analysis was applied to group sites characterized by similar relative frequency of the extreme water temperature timing. The Ward method was chosen for linking process. All statistical analysis was conducted in Statistica 12, while heat maps were prepared in Corel Draw 12. Catchment characteristics were calculated in the ArcMap 10.2 software on the basis of digital hydrographic maps, the digital terrain model SRTM, and the Corine Land Cover 2012 database.

\section{RESULTS}

\section{AIR AND WATER TEMPERATURE IN 2016}

The mean annual air temperature at Warsaw-Okęcie meteorological station for the study period reached $10.4^{\circ} \mathrm{C}$, which was higher than the typical long-term mean. The lowest mean monthly air temperature was noted in January $\left(-2.8^{\circ} \mathrm{C}\right)$, while the highest was observed in June $\left(20.1^{\circ} \mathrm{C}\right)$. Water temperature in the analysed sites generally followed the air temperature pattern. The highest mean monthly water temperature was noted, dependent on profile, in June or July, and reached from $18.4^{\circ} \mathrm{C}$ in site $\mathrm{U} 2$ to $21.6^{\circ} \mathrm{C}$ in site U3. Minimum mean monthly water temperature ranged from $0.2^{\circ} \mathrm{C}$ in site $\mathrm{S} 3$ to $1.8^{\circ} \mathrm{C}$ in site $\mathrm{U} 3$ and was observed in all sites in January. Overall, the lowest mean temperature during the hydrological year
2016 was found in site $\mathrm{U} 1\left(10.4^{\circ} \mathrm{C}\right)$, representing the smallest catchment with a high contribution of forested area, while the highest was observed in site U3 $\left(12.4^{\circ} \mathrm{C}\right)$, with a strong anthropogenic impact.

\section{DYNAMICS OF WATER TEMPERATURE}

Spatial and temporal patterns of monthly water temperature range were found in the case of all of the analysed profiles (Fig. 2). Generally, as it was presented on the example of the specific days in the year (Fig. 3), the smallest temperature variations were observed in the winter, they increased in the spring to reach maximum values in early summer, and then decreased again in the autumn. Thus, the highest mean monthly water temperature range was found in May or June, reaching from $2.2^{\circ} \mathrm{C}$ in $\mathrm{R} 1$ and $\mathrm{S} 3$ to even $6.0^{\circ} \mathrm{C}$ in $\mathrm{U} 1$, while the lowest was observed in all of the sites in January, reaching from only $0.1^{\circ} \mathrm{C}$ to $0.9^{\circ} \mathrm{C}$. A similar tendency was observed in the case of the maximum and minimum monthly temperature ranges. However, the minimum monthly temperature range was less variable in certain months, especially in the winter period.

On average, the highest temperature range was observed in site U1 in the upstream reach of the Utrata River $\left(2.8^{\circ} \mathrm{C}\right)$, while the lowest in site $\mathrm{R} 1\left(1.3^{\circ} \mathrm{C}\right)$ (Tab. 2). Generally, seasonal patterns of daily water temperature range were similar in small headwater catchments, e.g. J1, S1, and U1, where the water temperature was the most variable in the diurnal timescale (Fig. 2). Despite the similar channel and catchment properties in site R1, for example in terms of forested area, the temperature dynamics in this site was closer to sites J2, S3, and U3, which represent downstream parts of rivers with larger catchment areas (Fig 3). The largest differences between sites were visible in the summer half of the year, when the mean

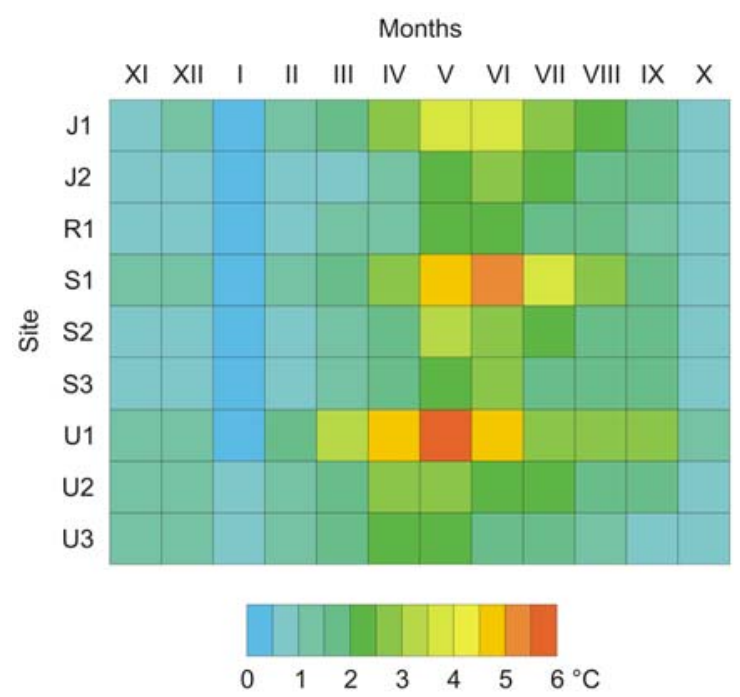

Fig. 2. Distribution of mean monthly water temperature ranges across all investigated sites in the hydrological year 2016; J1, J2, R1, S1, S2, S3, U1, U2, U3 = profiles as in Tab. 1; source: own study 
a)

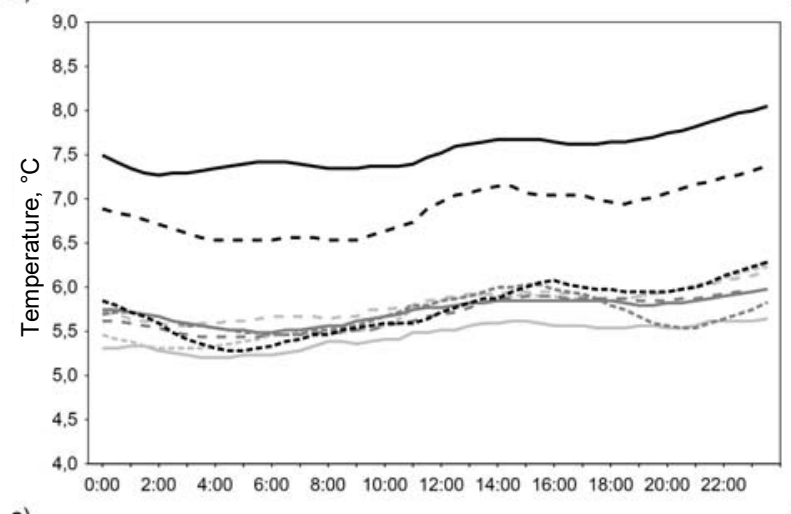

c)

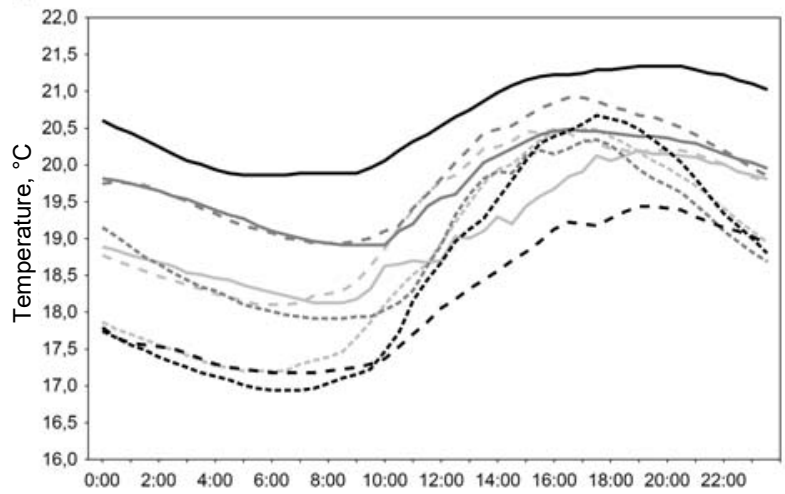

b)

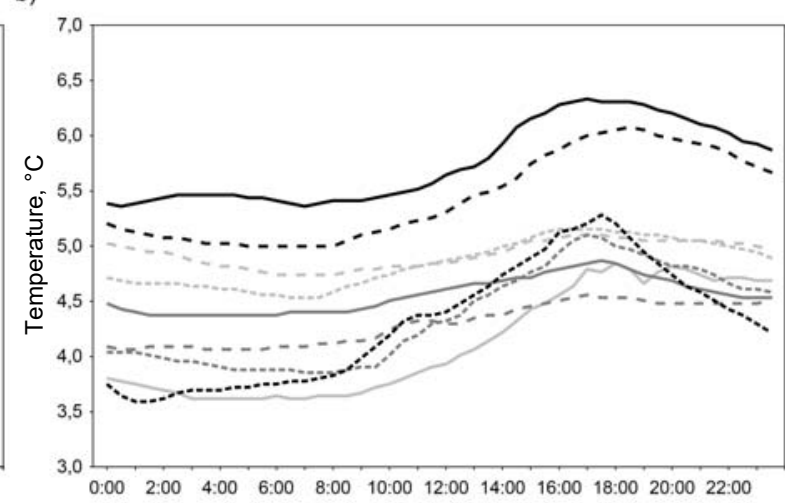

d)

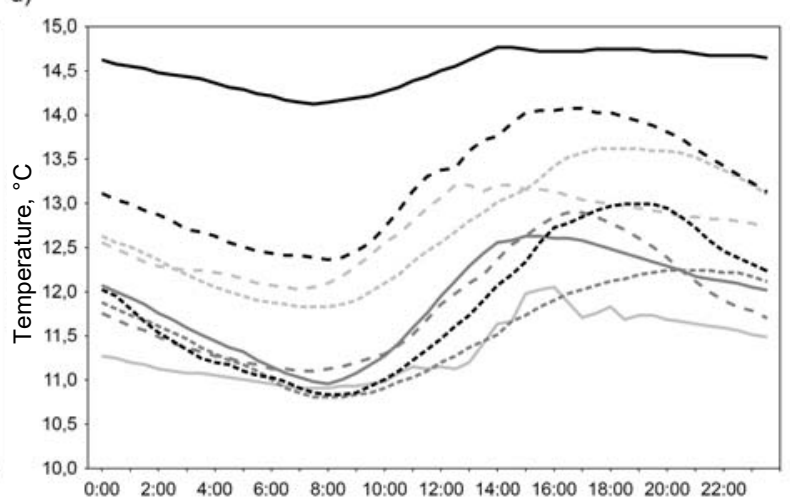

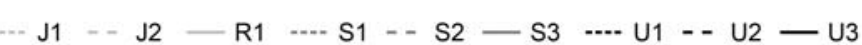

Fig. 3. Water temperature course in specific days of the year: a) $22^{\text {nd }}$ of December, b) $20^{\text {th }}$ of March, c) $21^{\text {st }}$ of June, d) $22^{\text {nd }}$ of September; J1, J2, R1, S1, S2, S3, U1, U2, U3 = profiles as in Tab. 1; source: own study

Table 2. Parameters of the daily water temperature range in investigated sites (profiles of river) during hydrological year 2016

\begin{tabular}{|c|c|c|c|c|c|c|c|c|c|c|c|c|c|c|}
\hline Parameter & Site & XI & XII & I & II & III & IV & $\mathrm{V}$ & VI & VII & VIII & IX & $\mathrm{X}$ & Year \\
\hline \multirow{9}{*}{$\begin{array}{c}\text { Mean daily } \\
\text { range } \\
{ }^{\circ} \mathrm{C}\end{array}$} & $\mathrm{J} 1$ & 1.0 & 1.1 & 0.4 & 1.3 & 1.7 & 3.0 & 3.9 & 3.6 & 2.6 & 2.3 & 2.0 & 1.0 & $2.0( \pm 0.07)$ \\
\hline & $\mathrm{J} 2$ & 0.9 & 1.0 & 0.3 & 0.8 & 1.0 & 1.5 & 2.5 & 2.9 & 2.3 & 2.0 & 1.7 & 0.7 & $1.5( \pm 0.05$ \\
\hline & $\mathrm{R} 1$ & 0.8 & 0.9 & 0.2 & 0.7 & 1.1 & 1.5 & 2.3 & 2.2 & 1.7 & 1.6 & 1.4 & 0.7 & $1.3( \pm 0.04)$ \\
\hline & S1 & 1.3 & 1.1 & 0.4 & 1.1 & 1.7 & 3.0 & 5.0 & 5.3 & 3.6 & 2.7 & 2.0 & 0.8 & $2.3( \pm 0.10)$ \\
\hline & S2 & 0.9 & 0.9 & 0.5 & 0.9 & 1.1 & 2.0 & 3.3 & 2.7 & 2.3 & 1.9 & 1.9 & 0.9 & $1.6( \pm 0.06)$ \\
\hline & S3 & 0.8 & 0.9 & 0.1 & 0.7 & 1.1 & 2.0 & 2.2 & 2.6 & 2.0 & 1.9 & 1.9 & 0.7 & $1.4( \pm 0.05)$ \\
\hline & U1 & 1.4 & 1.4 & 0.2 & 1.9 & 3.3 & 5.0 & 6.0 & 5.0 & 3.0 & 2.7 & 3.0 & 1.1 & $2.8( \pm 0.11)$ \\
\hline & U2 & 1.2 & 1.2 & 0.9 & 1.4 & 1.9 & 3.0 & 3.0 & 2.5 & 2.1 & 1.8 & 1.8 & 1.0 & $1.8( \pm 0.05$ \\
\hline & U3 & 1.2 & 1.3 & 0.8 & 1.3 & 1.6 & 2.3 & 2.5 & 2.0 & 1.6 & 1.3 & 0.9 & 0.7 & $1.5( \pm 0.05)$ \\
\hline \multirow{9}{*}{$\begin{array}{l}\text { Maximum } \\
\text { daily range } \\
{ }^{\circ} \mathrm{C}\end{array}$} & J1 & 2.6 & 4.1 & 1.6 & 2.2 & 4.0 & 5.3 & 5.2 & 5.6 & 4.5 & 3.7 & 2.7 & 2.6 & 5.6 \\
\hline & $\mathrm{J} 2$ & 2.2 & 3.3 & 1.3 & 1.7 & 2.5 & 3.0 & 3.7 & 4.3 & 4.1 & 3.2 & 2.4 & 1.9 & 4.3 \\
\hline & $\mathrm{R} 1$ & 2.2 & 3.1 & 1.0 & 1.9 & 2.6 & 2.7 & 4.4 & 3.4 & 3.3 & 2.8 & 2.4 & 2.5 & 4.4 \\
\hline & S1 & 3.6 & 3.9 & 2.8 & 2.3 & 4.1 & 5.5 & 7.9 & 8.6 & 5.7 & 4.5 & 2.8 & 2.0 & 8.6 \\
\hline & S2 & 2.4 & 3.0 & 1.5 & 2.3 & 2.4 & 3.5 & 4.4 & 4.2 & 4.2 & 3.3 & 2.6 & 2.1 & 4.4 \\
\hline & S3 & 2.1 & 3.2 & 1.8 & 1.7 & 2.8 & 2.7 & 3.5 & 4.2 & 3.8 & 3.1 & 2.7 & 1.8 & 4.2 \\
\hline & U1 & 3.0 & 4.7 & 1.5 & 3.2 & 6.9 & 8.7 & 8.2 & 7.9 & 4.9 & 4.4 & 4.1 & 2.9 & 8.7 \\
\hline & U2 & 2.8 & 4.0 & 1.8 & 2.4 & 4.6 & 5.4 & 4.9 & 3.9 & 3.7 & 2.9 & 2.8 & 2.6 & 5.4 \\
\hline & U3 & 3.2 & 4.6 & 3.7 & 2.5 & 3.4 & 4.9 & 4.8 & 2.9 & 2.9 & 2.3 & 1.4 & 2.1 & 4.9 \\
\hline \multirow{9}{*}{$\begin{array}{c}\text { Minimum } \\
\text { daily range } \\
{ }^{\circ} \mathrm{C}\end{array}$} & J1 & 0.4 & 0.3 & 0.0 & 0.6 & 0.3 & 0.7 & $\begin{array}{ll}1.8 \\
\end{array}$ & 1.7 & 0.8 & 0.5 & 1.1 & 0.2 & 0.0 \\
\hline & $\mathrm{J} 2$ & 0.3 & 0.2 & 0.0 & 0.3 & 0.3 & 0.5 & 0.9 & 1.3 & 0.8 & 0.6 & 0.9 & 0.1 & 0.0 \\
\hline & $\mathrm{R} 1$ & 0.1 & 0.1 & $\begin{array}{l}0.1 \\
\end{array}$ & 0.2 & $\begin{array}{l}0.1 \\
\end{array}$ & 0.4 & 1.2 & 1.0 & 0.7 & 0.9 & 0.5 & 0.2 & 0.1 \\
\hline & S1 & 0.4 & 0.2 & 0.0 & 0.4 & 0.5 & 0.5 & 1.3 & 2.4 & 1.1 & 1.4 & 1.0 & 0.2 & 0.0 \\
\hline & S2 & 0.2 & 0.2 & 0.1 & 0.2 & 0.3 & 0.5 & 1.5 & 0.8 & 0.6 & 1.0 & 1.1 & 0.3 & 0.1 \\
\hline & S3 & 0.3 & 0.3 & 0.0 & 0.2 & 0.3 & 0.6 & 0.9 & 1.0 & 0.7 & 0.5 & 0.6 & 0.2 & 0.0 \\
\hline & U1 & 0.4 & 0.1 & 0.0 & 0.8 & 0.4 & 1.5 & 1.6 & 1.5 & 1.0 & 1.0 & 1.2 & 0.3 & 0.0 \\
\hline & U2 & 0.4 & 0.3 & 0.3 & 0.6 & 0.3 & 0.6 & 1.2 & 1.3 & 0.6 & 0.8 & 1.3 & 0.1 & 0.3 \\
\hline & U3 & 0.3 & 0.4 & 0.0 & 0.6 & 0.3 & 0.4 & 1.2 & 1.1 & 0.7 & 0.6 & 0.5 & 0.2 & 0.0 \\
\hline
\end{tabular}

Explanations: note the standard errors of means in parentheses; sites (profiles of river) as in Tab. 1.

Source: own study. 
monthly temperature range varied up to $3.8^{\circ} \mathrm{C}$ in May (Tab. 2). In the winter half of the year differences between sites were definitely smaller. Furthermore, there was a decrease of the monthly mean temperature range with the river lengths, as well as the maximum range, however, this tendency was not observed in the case of the minimum range metric, which was uniform throughout all sites. Differences between daily water temperature ranges in all investigated sites, as confirmed by Kruskal-Wallis test, were statistically significant $(p<0.01)$. Multiple comparisons indicate that sites can be linked into two relatively homogenous groups in terms of the daily water temperature range: J2, R1, $\mathrm{S} 2, \mathrm{~S} 3$, and U3 (group of small range of temperature), and $\mathrm{J} 1, \mathrm{~S} 1, \mathrm{U} 1$, and $\mathrm{U} 2$ (group of moderate and high range of temperature).

\section{TIMING OF THE EXTREME VALUES}

Maximum and minimum water temperature occurred in the studied sites at different times of the day and the timing of these extreme values was clearly dependent on the season (Fig. 4). Minimum water temperature usually occurred in the early morning, from 06:00 to 10:00 CEST, while maximum water temperature was noted from 14:00 to 18:00 CEST (Figs. 3 and 4). Generally, during the summer half of the year the timing of the extreme water temperatures was definitely more concentrated, especially in the case of the minimum water temperature, which was reflected by higher relative frequency in certain hours (Fig. 4). In addition, during the summer half of the year no maximum and minimum water temperatures occurred from 16:00 to 22:00 CEST and from 06:00 to 10:00 CEST, respectively, with the exception of site $\mathrm{R} 1$. During the winter half of the year the timing of the maximum and minimum water temperatures was widely distributed, especially in the case of the maximum temperatures. It is worth noting that minimum water temperature occurred later more often during winter than in the summer, while the maximum water temperature was generally noted earlier as a result of different day length and heating/ cooling time. Spatially, the timing of the maximum and minimum water temperatures was generally similar throughout all sites; KruskalWallis test confirmed that there were no statistically significant differences $(p>0.01)$ of relative frequency between sites both in the case of the maximum and minimum values in the winter and summer halves of the year. However, hierarchical cluster analysis showed that in the summer half of the year clusters were produced with higher euclidean distance, which
Site

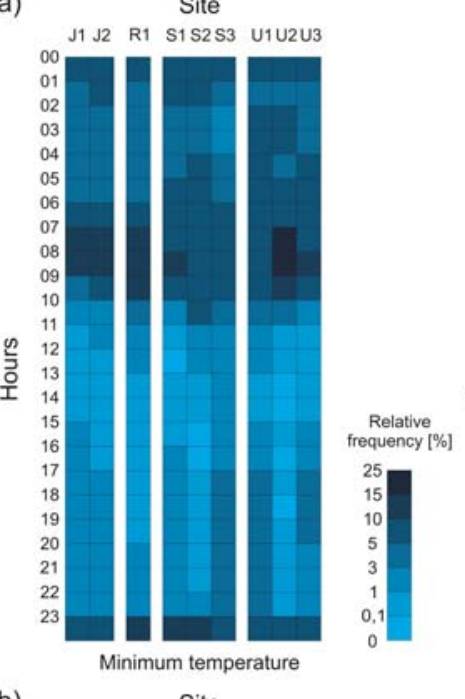

S1S2S3 U1U2U3

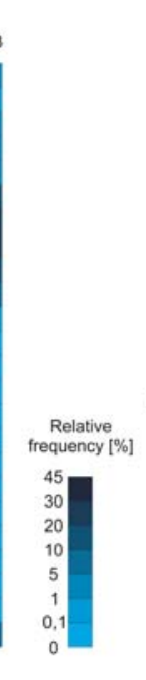

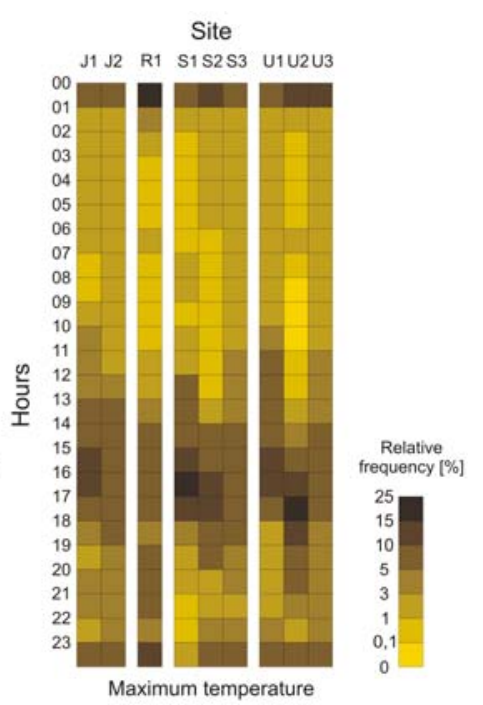

Site

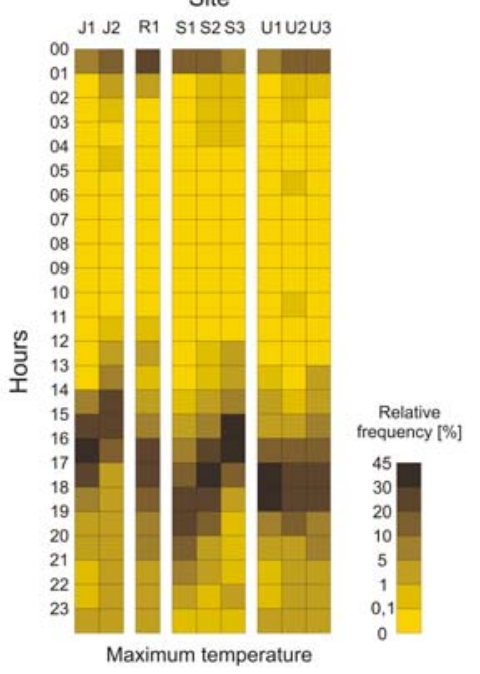

Fig. 4. Relative frequency of the maximum and minimum water erature timing in certain hours during the winter (a) and summer (b) halves of the year. Note the different scale in the winter (XI-IV) and summer (V-X); J1, J2, R1, S1, S2, S3, U1, U2, U3 = profiles as in Tab. 1; source: own study

indicated higher diversity of the extreme temperatures timing between investigated sites (Fig. 5). Moreover, especially in terms of maximum temperature timing, sites located within certain rivers were generally not linked closely, e.g. in the case of the Świder River in the upper, headwater reach (site S1) maximum water temperature occurred later, while minimum water temperature occurred earlier in the summer than in the case of downstream site S3 (Fig. 3c). An interesting tendency was found also in the summer half of the year in the case of sites J1, J2, and S3 - maximum water temperature appeared in these sites relatively earlier than in the other, which may be related with a high degree of riparian shade, effectively preventing solar radiation heating. Finally, there was a visible impact of anthropopressure, particularly in site R1 below a release from a pond, where maximum and minimum temperature timing was the most widely distributed and it was more similar to catchments with larger drainage area (site S3 and U3). 
a)

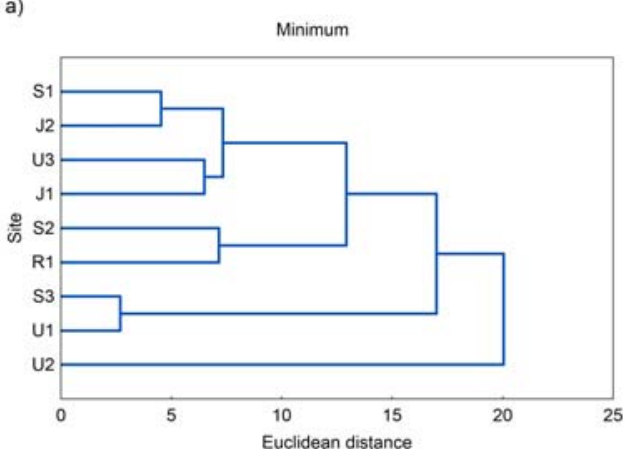

b)

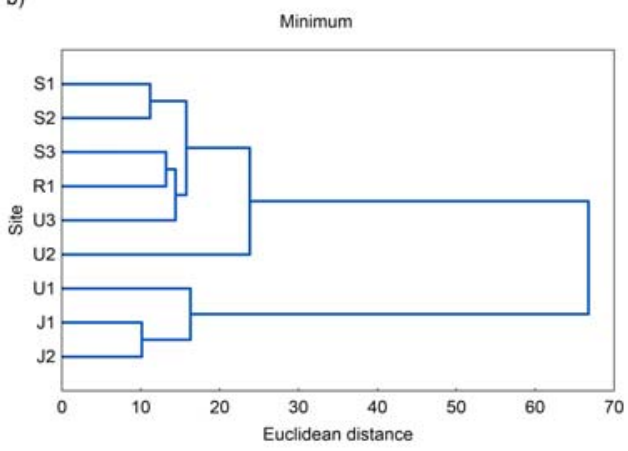

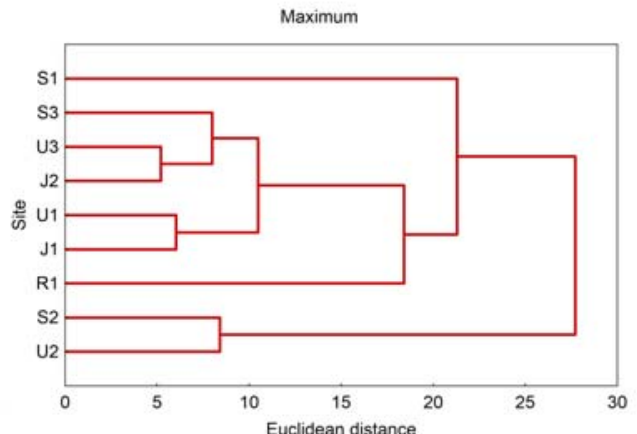

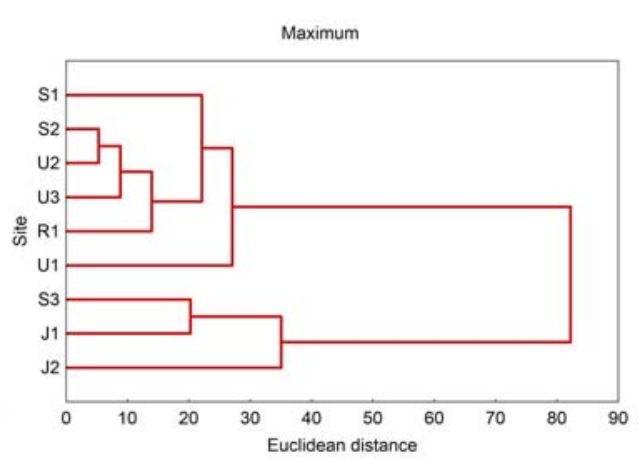

Fig. 5. Dendrograms produced for relative frequency of the maximum and minimum water temperature timing during the halves of the year: a) winter (XI-IV), b) summer (V-X); J1, J2, R1, S1, S2, S3, U1, U2, U3 = profiles as in Tab. 1; source: own study

\section{DISCUSSION}

High-resolution water temperature data allowed for the assessment of spatial and seasonal daily water temperature dynamics in small lowland rivers. Despite slightly elevated air temperature during the study period, which made water temperature potentially higher due to linear relationships between this two variables [CAISSIE 2006], the obtained results are proved to be quite representative, especially in terms of the spatial variability of temperature dynamics.

As presented in the previous research, the river energy budget is primarily controlled by radiative heat fluxes, particularly short-wave radiation and longwave radiation; this last component is responsible both for heat gains and losses [BENYAHYA et al. 2011; CAISSIE 2016]. However, the contribution of nonradiative components, such as bed conduction, sensible and latent heat flux, cannot be omitted [EvANS et al. 1998]. Heat fluxes are modified by several natural factors, such as the width and depth of the channel, as well as the shading of the water surface; there are also varied human impacts, such as water inflows and abstractions [CAISSIE 2006; WEBB, ZHANG 1997]. Results of the current study confirm the findings of river energy budget studies - the highest daily dynamics were observed in the summer, when atmospheric heat fluxes reached maximum intensity, while the lowest during the winter, which was associated with the appearance of ice phenomena. However, the fact that the highest temperature dynamics were observed in April and May is an interesting pattern - it can be explained that in these months riparian vegetation is just beginning to develop, while simultaneously atmospheric heat fluxes are reaching high values, mainly due to high solar angle and high air temperature. In July and August, despite high air temperature and radiative fluxes, which make good potential conditions for significant temperature variations, riparian shade efficiently blocks solar radiation, reducing daily temperature fluctuations [GARNER et al. 2014]

The streamflow rate also plays an important role in the moderation of daily temperature variations, because water temperature is directly dependent on heat energy dispressed in a certain volume of water [POOLE, BERMAN 2001]. During the winter half of the year streamflow rates are generally higher, making water column thermally stable and more resistant to atmospheric heat fluxes. This was also the reason behind definitely higher temperature dynamics in small catchments (proxy for low streamflow rates), where streams are easily heating and cooling despite the relatively high degree of riparian shade and high participation of forests in the catchment area, which was particularly observed in site U1.

Human impacts were clearly reflected in daily temperature variations. Site R1 saw reduced dynamics due to water releases from a pond, where temperature changed slowly due to the large volume of the water; such an influence of small ponds was previously suggested by BARTNIK et al. [2013], who studied changes in water quality of Dzierżązna and Sokołówka rivers, which are flowing through the cascades of small reservoirs. Sewage inflows from municipal wastewater 
treatment plants, which are one of the most important factors of thermal alternation in urbanized catchments [KINOUCHI et al. 2007], were also found to affect temperature dynamics in the current study; this was observed in the case of site U2 and U3, where the dynamics of the temperature in the summer were damped and much smaller than in the case of sites with similar catchment area. Sewage temperature across the whole year ranged approximately from 10 to $20^{\circ} \mathrm{C}$, which during the winter months caused higher temperature dynamics (and unnaturally high mean temperature), observed both in the sites U2 and U3.

Results of the timing of the maximum and minimum water temperatures during the day are generally consistent with previous investigations on stream temperature dynamics in other geographical regions (e.g. BROWN et al. [2010], BROADMEADOW et al. [2011], BAE et al. [2016]). However, it was interesting that during the winter a non-sinusoidal daily water temperature pattern appeared definitely more often than in the summer, which was reflected in the wider distribution of minimum and maximum temperatures throughout the hours. This can be explained by the fact that in the winter period radiative heat fluxes are relatively less important due to a low solar angle and cloudy days, while simultaneously the contribution of sensible heat flux on the river energy budget is more essential [EvANS et al. 1998; WEBB, ZHANG 1997]. This, together with less importance of riparian shade, may be also the reason for similar timing of the extreme water temperatures between sites during the winter half of the year. Evaluation of the timing of the extreme temperatures can also lead to the methodical conclusions about water temperature monitoring in Poland conducted by IMGW-PIB. In light of the obtained results, measurements carried out only once a day, at 06:00 UTC, can be a relatively good representation only of daily minimum values. It seems greatly incorrect to consider such values as mean daily water temperature, which may be several degrees higher. This suggests great caution in interpretations based on data from IMGW-PIB water temperature monitoring. However, the appearance of automatic measurements of temperature at a number of gauging stations a few years ago will definitely improve the quality of the data.

Finally, the results have also a practical aspect in the context of angling and game fisheries. During summer months in lowland rivers higher activity of salmonid fish like brown trout, which are considered as coldwater species [ELLIOTT, ELLIOTT 2010], can be expected in the early morning, when water temperature is the coldest, and, in consequence, the dissolved oxygen level is the highest. The opposite situation can be expected in the case of warmwater species, such as cyprinind fish (e.g. chubs, roaches, daces) [ELLIOTT 1981], the activity of which tends to be higher in the afternoon. During the winter half of the year, especially from December to February, due to insignificant daily temperature variations fish activity will proba- bly be less related to water temperature, so other abiotic and biotic factors are perhaps more important.

\section{CONCLUSIONS}

1. Water temperature dynamics of lowland rivers during the hydrological year 2016 had a clear seasonal pattern; the highest variations of water temperature were observed in May and June, when mean monthly temperature range reached even $6.0^{\circ} \mathrm{C}$, while the lowest were observed in January, with the mean monthly range of only $0.9^{\circ} \mathrm{C}$.

2. Statistically significant differences were found in the daily water temperature range between groups of the investigated sites; a higher diurnal temperature range was observed in headwater sites draining a smaller catchment area, while larger catchments were generally more thermally stable in the daily timescale. Human impacts such as impoundments and sewage inflows caused a decrease in daily water temperature dynamics.

3. All investigated sites exhibited sinusoidal daily water temperature pattern with the maximum water temperature usually occurred in the morning, from 06:00 to 10:00 CEST, and minimum temperature occurred in the afternoon, from 14:00 to 18:00 CEST. A non-sinusoidal daily water temperature pattern appeared definitely more often during the winter half of the year than in the summer, which was reflected in the wider distribution of minimum and maximum temperatures throughout the hours. Spatially, the timing of the maximum and minimum water temperatures was similar in all of the investigated sites, with no statistically significant differences; however, in the summer half of the year the timing of the extreme temperatures was more varied between investigated sites.

\section{Acknowledgements}

Two anonymous reviewers are acknowledged for their helpful and essential comments. Research has been partially funded by the University of Warsaw (grant number 501/86DSM-110600).

\section{REFERENCES}

Bae M.J., Merciai R., Benejam L., Sabater S., GarciaBERTHOU E. 2016. Small weirs, big effects: Disruption of water temperature regimes with hydrological alternation in a Mediterranean stream. River Research and Applications. Vol. 32 p. 309-319.

Bartnik A., Moniewski P., TOMALSKi P. 2013. Seasonality of the basic physical and chemical characteristics of water flowing through the cascades of small reservoirs. Limnological Review. Vol. 13. No. 2 p. 63-71.

Benyahya L., Caissie D., Satish M.G., El-Jabi N. 2012. Long-wave radiation and heat flux estimates within a small tributary in Catamaran Brook (New Brunswick, Canada). Hydrological Processes. Vol. 26. No. 4 p. 475-484.

Broadmeadow S.B., Jones J.G., LangFord T.E.L., Shaw P.J., NisBET T.R. 2011. The influence of riparian shade 
on lowland stream water temperatures in southern England and their viability for brown trout. River Research and Applications. Vol. 27 p. 226-237.

Brown L.E., CoOper L., Holden J., RAMCHUnder J. 2010. A comparison of stream water temperature regimes from open and afforested moorland, Yorkshire Dales, northern England. Hydrological Processes. Vol. 24 p. 3206-3218.

CAISSIE D. 2006. The thermal regime of rivers: A review. Freshwater Biology. Vol. 51. No. 8 p. 1389-1406.

CAISSIE D. 2016. River evaporation, condensation and heat fluxes within a first order tributary of Catamaran Brook (New Brunswick, Canada). Hydrological Processes. Vol. 30. No. 12 p. 1872-1883.

ElliotT J.M. 1981. Some aspects of thermal stress on freshwater teleosts. In: Stress and fish. Eds. A.D. Pickering. New York. Academic Press p. 209-245.

ElliotT J.M., EliotT J.A. 2010. Temperature requirements of Atlantic Salmon Salmo salar, brown trout Salmo trutta and Arctic charr Salvelinus alpinus: predicting the effects of climate change. Journal of Fish Biology. Vol. 77. No. 8 p. $1793-1817$.

Evans E.C., McGregor G.R., Petts G.E. 1998. River energy budgets with special reference to river bed processes. Hydrological Processes. Vol. 12 p. 575-595.

Garner G., Malcolm I.A., SAdler J.P., Hannah D.M. 2014. What causes cooling water temperature gradients in a forested stream reach? Hydrology and Earth System Science. Vol. 18 p. 5361-5376.

JOHNSON M.F., WILBY R.L. ToONE J.A. 2014. Inferring airwater temperature relationships from river and catchment properties. Hydrological Processes. Vol. 28. No. 6 p. 2912-2928.

KinOuChi T., Yagi H., MiYamoto M. 2007. Increase in stream temperature related to anthropogenic heat input from urban wastewater. Journal of Hydrology. Vol. 335 p. $78-88$.

ŁASZEWSKI M. 2013. Stream water temperature: A short review with special reference to diurnal dynamics. Miscellanea Geographica - Regional Studies on Development. Vol. 17. No. 1 p. 34-41.

ŁASZEWSKI M. 2016. Relationships between environmental metrics and water temperature: A case study of Polish lowland rivers. Water and Environment Journal. Vol. 30. No. 1-2 p. 143-150.

Malcolm I.A., Hannah D.M., Donaghy M.J., Soulsby C., YounGSON A.F. 2004. The influence of riparian woodland on the spatial and temporal variability of stream water temperatures in an upland salmon stream. Hy- drology and Earth System Science.Vol. 8. No. 3 p. 449459.

Marszelewski W., Pius B. 2015. Long-term changes in temperature of river waters in the transitional zone of the temperate climate: A case study of Polish rivers. Hydrological Sciences Journal. Vol. 61. No. 8 p. 14301442.

Oligny-Hebert H., Senay C., Enders E.C., Boisclair D. 2015. Effects of diel temperature fluctuation on the standard metabolic rate of juvenile Atlantic salmon (Salmo salar): Influence of acclimation temperature and provenience. Canadian Journal of Fisheries and Aquatic Sciences. Vol. 72. No. 9 p. 1306-1315.

Poole G.C., Berman C.H. 2001. An ecological perspective on in-stream temperature:natural heat dynamics and mechanisms of human-caused thermal degradation. Environmental Management. Vol. 27 p. 787-802.

RAJWA-Kuligiewicz A., BIALIK R.J., ROWIŃSKi P.M. 2015. Dissolved oxygen and water temperature dynamics in lowland rivers over various timescales. Journal of Hydrology and Hydromechanics. Vol. 63. No. 4 p. 353363.

SKOWRON R., PIASECKI A. 2016. Dynamics of the daily course of water temperature in Polish lakes. Journal of Water and Land Development. No. 31 p. 149-156. DOI 10.1515/jwld-2016-0046.

Vannote R.L., Minshall G.W., Cummins K.W., Sedell J.R., CUSHING C.E. 1980. The river continuum concept. Canadian Journal of Fisheries and Aquatic Sciences. Vol. 37 p. 130-137.

Webi B.W., Hannah D.M., Dan Moore R., Brown L.E., NoBILIS F. 2008. Recent advances in stream and river temperature research. Hydrological Processes. Vol. 22 p. $902-918$.

WeBB B.W., ZhANG Y. 1997. Spatial and seasonal variability in the components of the river heat budget. Hydrological Processes. Vol. 11 p. 79-101.

WIEJACZKA Ł. 2007. Dobowy cykl temperatury wody w rzece Ropie poniżej zbiornika retencyjnego w Klimkówce [Twenty-four hour cycle of the temperature of water in the Ropa River below water reservoir in Klimkówka]. Monitoring Środowiska Przyrodniczego. T. 8 p. 91-98.

ŻELAZNY M. 2012. Czasowo-przestrzenna zmienność cech fizykochemicznych wód Tatrzańskiego Parku Narodowego [Spatio-temporal variability of physical and chemical characteristics of waters of the Tatra National Park]. Kraków. IGiGP UJ. ISBN 978-83-88424-80-9 pp. 285.

\section{Maksym A. LASZEWSKI}

\section{Dobowa dynamika temperatury wody w rzekach nizinnych: Studium przypadku z centralnej Polski}

\section{STRESZCZENIE}

Celem pracy było określenie przestrzennego i sezonowego zróżnicowania dobowej dynamiki temperatury wody w niewielkich rzekach nizinnych. Dane pomiarowe uzyskano za pomocą cyfrowych rejestratorów temperatury wody, które zlokalizowano w dziewięciu profilach rzek Mazowsza w roku hydrologicznym 2016. Na podstawie danych pomiarowych obliczono średni, maksymalny i minimalny dobowy zakres temperatury w ujęciu miesięcznym, a także względną częstość występowania ekstremalnych wartości temperatury w poszczególnych godzinach. Wyniki wskazują, że dobowa dynamika temperatury wody odznaczała się wyraźną sezonową zmien- 
nością; największe dobowe wahania temperatury wody były obserwowane w maju i czerwcu, natomiast najmniejsze w styczniu. Wykazano ponadto istotne statystycznie różnice zakresu dobowego temperatury wody między analizowanymi profilami; większy zakres dobowy był charakterystyczny dla profili pomiarowych zamykających zlewnie o mniejszej powierzchni, natomiast większe rzeki były na ogół bardziej stabilne termicznie. Stwierdzono również wyraźny wpływ antropopresji na dobową dynamikę temperatury wody, przede wszystkim w postaci zrzutów wody ze stawów oraz zbiorników, jak również ścieków z oczyszczalni. Temperatura minimalna występowała w przypadku badanych rzek najczęściej rano - od 06:00 do 10:00 CEST, natomiast temperatura maksymalna późnym popołudniem - od 14:00 do 18:00 CEST. Okres występowania ekstremalnych wartości temperatury wody w ciągu dnia był zbliżony; metoda aglomeracji wykazała jednak, że w półroczu letnim zaobserwowano większe zróżnicowanie czasu występowania wartości ekstremalnych, szczególnie temperatury maksymalnej. Wyniki badań wzbogacają wiedzę dotyczącą warunków termicznych wód płynących, wydają się również interesujące w kontekście wędkarstwa sportowego oraz rybactwa.

Słowa kluczowe: centralna Polska, dobowa dynamika, rzeki nizinne, temperatura wody 